\title{
Sebab dan Akibat Kepuasan Kerja Dosen Swasta di Kota Pekanbaru
}

\author{
NOVITA \\ Sekolah Tinggi Ilmu Ekonomi Riau \\ Jln. HR Subrantas KM 12 Panam (0761) 63237 \\ E-mail : novita@lecturer.stieriau.akbar.ac.id
}

\begin{abstract}
Lecturers as educators tasked with implementing the Tri Dharma of Higher Education are always faced with performance problems. The impact of the certification of professional lecturers to lecturers in universities requires performance every semester from lecturers. This has become a rule of government policy to improve the professionalism of lecturers in their work. But there are many performance problems that seem to only complete tasks and responsibilities. Quantitatively, performance is carried out, but in quality it is still not as expected. Other problems such as working satisfaction of lecturers in expressing themselves as educators are still not optimal, coupled with the obligation problem is present with a presence attendance system of lecturers who are used up to come to campus, while research and service assignments are not done on campus. Then also the problem of the reward system applied and also the reward system given. This is sad when seen in a special high school private college. Through the use of the field survey method using an online questionnaire distributed to 40 private lecturers at the level of high school economics in Pekanbaru with purposive sampling technique and data were analyzed using SEM through WarpPLS software. The results showed that lecturer job satisfaction was proven to be influenced by the reward system applied on campus, but was not influenced by the presence attendance system and the reward system. Then lecturer job satisfaction has an impact on the performance of private lecturers carrying out teaching, research and also carrying out community service.
\end{abstract}

Keywords: Job Satisfaction, Private Lecturer

\begin{tabular}{|c|c|}
\hline $\begin{array}{l}\text { Berdirinya perguruan tinggi menjadi } \\
\text { sebuah lembaga yang bertugas untuk } \\
\text { menyebarluaskan pengetahuan dan } \\
\text { wawasan kepada generasi muda. Lembaga } \\
\text { ini berperan aktif dalam rangka } \\
\text { mencerdaskan kehidupan bangsa, } \\
\text { kecerdasan anak bangsa akan menjadi titik } \\
\text { tolak kecerasan bangsa itu sendiri. Melalui } \\
\text { lembaga pendidikan tinggi, berbagai upaya } \\
\text { dilakukan dalam tujuan yang dimaksud. } \\
\text { Terdapat banyak unsur yang terlibat dalam } \\
\text { sebuah lembaga pendidikan tinggi salah } \\
\text { satunya adalah dosen. } \\
\text { profesional yang untuk mendapatkan } \\
\text { kedudukan tersebut mereka harus } \\
\text { memenuhi perangerti } \\
\text { berpendidikan minimal magister dan linier } \\
\text { dan juga mampu melaksanakan kegiatan } \\
\text { dengan bentuk kewajibannya antara lain: } \\
\text { melaksanakan pengajaran dan juga } \\
\text { melakasnakan pendidikan, kemudian juga }\end{array}$ & $\begin{array}{l}\text { melaksanakan penelitian sesuai dengan } \\
\text { bidang keilmuan dan juga melaksanakan } \\
\text { pengabdian sesuai dengan bidang ilmu. } \\
\text { (UU RI, No } 14 \text { Tahun 2005). } \\
\text { Dosen sebagai tenaga pendidik } \\
\text { memiliki tugas melaksanakan Tri Dharma } \\
\text { perguruan tinggi. Dharma pertama adalah } \\
\text { melaksanaan pendidikan dan pengajaran, } \\
\text { pendidikan dan pengajaran tidak saja } \\
\text { wujud kinerja dosen hanya mengajar } \\
\text { sahaja, namun mempersiapan bahan ajar } \\
\text { dan juga melakukan evaluasi terhadap } \\
\text { peserta didik menjadi pekerjaan rutin } \\
\text { namun tidak tampak. Kemudian Dharma } \\
\text { yang kedua adalah melakukan penelitian, } \\
\text { dimana dosen melakukan penelitian dalam } \\
\text { rangka pengembangan ilmu pengetahuan } \\
\text { karena dijelaskan bahwa dosen } \\
\text { professional adalah dosen yang bisa } \\
\text { belajar mandiri. Hal ini dilakukan dalam } \\
\text { rangka mewujudkan sebuah kebaruan }\end{array}$ \\
\hline
\end{tabular}


ketiga adalah berkaitan dengan pengabdian kepada masyarkaat, ini dikaitkan dengan peran dosen pada masyarakat. Ilmu yang dimiliki dan dikembangkan melalui penelitian diabdikan dimasyarakat sehingga tidak hanya warga kampus yang mendapatkan perubahan wawasan, namun juga masyarakat itu serta menikmati perkembangan ilmu dan teknologi yang dimiliki dosen.

Permasalahan saat ini sebagaimana bila dilihat pada perguruan tinggi swasta, dimana dengan sistem penghasilan yang diterapkan pada dosen yang sangat bervariatif dimana dosen diminta untuk kerja iklas dan kerja cerdas sedangkan gaji yang diterima sangat miris dan sangat besar tuntutan waktu yang diberikan kepada dosen, membuat dosen kurang kreatif dalam bekerja dan seakan dosen mengalami tekanan dalam bekerja. Kerja harus dipertanggungjawabkan dan laporannya ditunggu. Pada sisi lain dosen memiliki tanggungan membiayai keluarga dan kondisi ini tidak sebanding dari hasil yang diperoleh melalui bekerja sebagai dosen dan mengakibatkan kerja dosen asal siap. Kepuasan dosen menjadi semakin kurang mengaktualisasikan diri dalam kehidupannya.

Persoalan lainnya berkenaan dengan masalah kinerja dosen ini yakni dengan sistem penghargaan dan juga sistem presensi dan juga sistem pengupahan yang dikaitkan dengan persoalan kepuasan dan juga persoalan kinerja dosen. Penelitian ini mencoba melihat pengaruh yang ditimbulkan dengan sistem penggajian dan juga sistem presensi kehadiran akibat dari persepsi terhadap 12 jam perminggu diwajibkan kepada dosen bersetifikat professional dan juga sistem penghargaan yang diberikan kepada dosen. Hal ini dikaitkan dengan kepuasan kerja yang dosen rasakan dan juga akibatnya kepada kinerjanya.

Penelitian dilakukan pada dosen swasta di Kota Pekanbaru karena Pekanbaru sebagai salah satu barometer dalam perkembangan pendidikan di
Propinsi Riau. Hal ini akan menjadikan Pekanbaru contoh lain dan juga dapat menggambarkan kondisi yang sama dibandingkan dengan daerah lainnya dan karena juga Pekanbaru tempat berkumpulnya perguruan tinggi swasta.

Oleh karena itu, maka penulis tertarik melakukan penelitian dengan ingin membuktikan apakah sistem penggajian, sistem presensi kehadiran dan sistem penghargaan berpengaruh terhadap kepuasan kerja dan apakah kepuasan kerja berdampak kepada kinerja dosen swasta di Kota Pekanbaru.

Berdasarkan banyak literatur yang membahasa berkenaan dengan kinerja dan kepuasan kerja menurut Rosita, S. (2014) terdapat banyak persoalan yang dihadapi dosen dalam melaksanakan pekerjaannya khususnya tri dharma. Permasalahaan yang umum dianyartanya adalah stres dalam bekerja, tekanan menghadapi mahasiswa dan juga tekanan dari pekerjaan yang menjadi tanggungjawabnya. Juga masalah hubungan interpersonal dan juga masalah peran ganda khusus bagi dosen perempuan yang satu sisi melaksanakan tri dharma dan sisi lain sebagai ibu rumah tangga.

Kemudian juga menurut Karniawati, N. (2013) peran perempuan sebagai dosen memberikan peran ganda dan ternyata dosen perempuan lebih efektif dalam melaksanakan pekerjaan pendidik bila dibandingkan dengan dosen laki-laki.

Dari pendapat tersebut dapat diketahui bahwa pekerjaan sebagai dosen tidak hanya dilakukan oleh laki-laki, perempuan juga memberikan andil yang cukup besar dan terkesan lebih efektif.

Selain itu juga terdapat beberapa dimensi yang digunakan dalam mengukur kinerja dosen antara lai: hasil kerja, kualitas kerja, kehadiran kerja dan juga kerjasama sana yang dibangun (Tewal, B., \& Tewal, F. B, 2014).

Dari beberapa pendapat di atas, maka dapat dikatakan bahwa kinerja dosen adalah hasil kerja yang dilakukannya dalam melaksanakan fungsi pengajaran dan juga fungsi penelitian serta fungsi pengabdian 
pada masyarkat dengan indikator pengukurannya dilihat dari: 1) kelas mengajar; 2) penelitian yang dihasilkan; 3) pengabdian yang dilakukan dan 4) sertifikat yang dihasilkan.

Banyak faktor yang mempengaruhi kinerja dosen, diantaranya adalan faktor kepuasan kerja. Sebagaimana dijelaskan dari beberapa pendapat seper menurut hasil penelitian Engko, C. (2008) bahwa adanya kaitan yang erat variabel kepuasan kerja dengan kinerja karyawan dalam bekerja. Selanjutnya menurut Sudiro, A. (2009) juga demikian khusus tenaga pendidik (dosen), kepuasan kerja berdampak terhadap kinerja mereka. Juga disampaikan oleh Awaluddin, M. (2016) adanya kaitan yang kuat antara kepuasan kerja dan juga kinerja dosen.

Dari variabel kepuasan kerja dosen dalam bekerja, dapat juga diketahui bahwa terdapat banyak faktor yang mempengaruhi kepuasan kerja dosen diantaranya men Ariati, J. (2010) yakni adanya faktor penghargaan. Menurut Hersusdadikawati, E. (2005) yakni faktor gaji dan juga keinginan untuk berpindah kerja dan juga variabel komitmen organisasional. Juga disampaikan oleh Gandhi, M. A. (2017) yakni penerapan absensi Finger Print dapat mendisiplinkan kerja serta pendapat Ilmiana, Z. (2016) yakni faktor penerapan Sistem Absensi Manual dan Finger Print.

Dari uraian tersebut, maka dapat dibuat hipotesis: sistem imbalan, presensi dan penghargaan terhadap kepuasan kerja dosen baik secara simultan maupun secara parsial pada dosen swasta di Kota Pekanbaru dan juga diduga kepuasan kerja berpengaruh terhadap kinerja dosen swasta Perempuan di Kota Pekanbaru.

\section{METODE}

Penelitian dilaksanakan di Kota
Pekanbaru dimana ruang lingkup
pengumpulan data mencangkup pada seluruh
dosen swasta perempuan di Kota Pekanbaru.
Pada penelitian ini yang menjadi objek/
peubah yang diamati, adalah dosen
perempuan yang tersebar di 40 perguruan

tinggi swasta di Pekanbaru sehingga setiap perguruan tinggi diwakili 1 orang.

Data primer adalah data yang diperoleh dari pengamatan dan observasi secara angsung terhadap obyek yang diteliti melalui kuesioner. Dalam hal ini pengurus dosen perempuan yang diperoleh melalui kuesioner. Sedangkan data sekunder adalah data yang diperoleh dari instansi-instansi atau lembaga yang berkaitan dengan penelitian ini, misalnya studi literature terdahulu, studi kepustakaan, jurnal literatur-literatur yang berkaitan dengan permasalahan.

Analisa data dalam penelitian ini menggunakan metode deskriptif kuantatif yaitu suatu metode dengan mengelompokan data kedalam suatu distribusi frekuensi dan kemudian dianalisis dan dikaitkan dengan teori yang ada setelah itu baru dibuat suatu kesimpulan. Uji validitas dan uji reliabilitas serta uji normalitas dilakukan dalam penelitian ini untuk memastikan data normal dan juga layak digunakan dalam pengukuran statistic parametric.

Analisis SEM dengan menggunakan software WarpPLS digunakan untuk membuktikan hipotesis baik secara simultan maupun secara parsial dari variabel yang diamati.

\section{HASIL}

Berdasarkan hasil pengolahan data dengan menggunakan program WarpPLS, dimulai dari uji instrument yakni mengunakan uji validitas dan reliabilitas semua variabel valid dan reliable dan juga uji normalitas data sehingga dapat digunakan alat analisis SEM. Dapat dilihat pada gambar berikut ini:

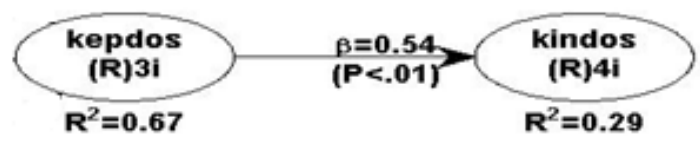

\section{Gambar 1 : Full Model SEM}

Hasil penelitian menunjukkan bahwa kepuasan kerja dosen terbukti dipengaruhi oleh sistem imbalan yang diterapkan di kampus, tetapi tidak 
dipengaruhi oleh sistem presensi kehadiran dan juga sistem penghargaan. Kemudian kepuasan kerja dosen berdampak kepada kinerja dosen dalam melaksanakan Tri Dharma Perguruan Tinggi.

Apabila diuraikan dapat diketahui bahwa pengaruh sistem imbahan signifikan dengan nilai signifikansi sebesar 0.01 lebih kecil dari 0.05 dan beta sebesar 0.79 yang berpengaruh positif. Kemudian pegaruh sistem presensi tidak signifikan dengan nilai signifikansi sebesar 0.45 lebih besar dari 0,05 dan nilain beta 0.01. Juga pengaruh faktor sistem penghargaan dengan nilai signifikansi sebesar 0.29 juga lebih besar dari 0.05 dengan beta sebesar 0.05. ini juga menunjukkan tidak signifikan terhadap kepuasan kerja. Sedangkan pengaruh kepuasan terhadap kinerja pegawai sebesar 0.01 lebih kecil dibandingkan dengan 0.05 menunjukkan pengaruh yang signifikan terhadap kinerja dosen perempuan.

\section{PEMBAHASAN}

Kinerja dosen perempuan di Kota Pekanbaru dalam kategori baik dengan skor 3.38. Ini menunjukkan bahwa dosen perempuan di Kota Pekanbaru sudah cukup baik dalam melaksanakan tugasnya sebagai tenaga pendidik. Dari tiga indikator dapat diketahui indikator tertinggi berada pada melaksanakan pengabdian dan terendah adalah adalah pada kualitas penunjang. Dosen perempuan masih kurang aktif dalam kegiatan-kegiatan sekstra seperti seminar, menjadi pejabat dalam sebuah organisasi. Hal ini lebih karena dosen perempuan memiliki pekerjaan utama yakni mengurus keluarga.

Kepuasan kerja dosen perempuan dengan skor 2.6 masuk dalam kategori kurang baik. Ini menunjukkan bahwa dosen perempuan dalam bekerja sebagai dosen merasa kurang puas. Dari tiga indikator yang digunakan untuk mengukur kepuasan kerja dapat dilihat indikator tertinggi pada puas dengan rekan sejawat dan paling rendah adalah pada kurang puas dalam menerima perlakuan dari lembaga kepadanya.

Sistem imbalan yang diterapkan di kampus menurut dosen perempuan, yakni dengan skor 2,23 masuk dalam kategori kurang baik. Ini menunjukkan bahwa dosen perempuan menganggap bahwa imbalan yang dibayarkan kepada dosen perempuan tidak sesuai dengan aturan pemerintah. Walaupun mereka menyatakan sudah sesuai dengan apa yang diberikan dengan apa yang diterimanya.

Sistem presensi menurut dosen perempuan kurang diterapkan dengan baik, hal ini dapat dilihat dari skor yang dihasilkan menunjukkan bahwa 2.53masuk dalam kategori kurang baik. Hal ini disebabkan adanya anggapan dari dosen perempuan bahwa bekerja sebagai dosen bukan seperti bekerja sebagai karyawan pada sebuah perusahaan. Karena dosen merupakan jabatan professional jadi kehadiran bukan hal yang perlu di lakukan.

Sistem penghargaan yang diberikan sudah cukup baik. Dimana dari tiga indikator yang digunakan diketahui indikator yang paling rendah adalah pada sistem penghargaan hibah. Hal ini adanya anggapan bahwa melalui program hibah dikti, hal ini menjadi sebuah prestasi bagi dosen dengan diberikan penghargaan dalama bentuk ucapan selamat dari pimpinan akan menjadi sebuah bentuk apresiasi dari lembaga atas prestasi yang diraih dosen.

Pengaruh sistem imbahan signifikan dengan nilai signifikansi sebesar 0.01 lebih kecil dari 0.05 dan beta sebesar 0.79 yang berpengaruh positif. Kemudian pegaruh sistem presensi tidak signifikan dengan nilai signifikansi sebesar 0.45 lebih besar dari 0,05 dan nilain beta 0.01. Juga pengaruh faktor sistem penghargaan dengan nilai signifikansi sebesar 0.29 juga lebih besar dari 0.05 dengan beta sebesar 0.05. ini juga menunjukkan tidak signifikan terhadap kepuasan kerja.

\section{SIMPULAN}

Berdasarkan hasil penelitian tersebut, maka dapat diambil kesimpulan sebagai berikut:

1. Kinerja dosen perempuan di Kota 
Pekanbaru dalam kategori baik dengan skor 3.38. Ini menunjukkan bahwa dosen perempuan di Kota Pekanbaru sudah cukup baik dalam melaksanakan tugasnya sebagai tenaga pendidik. Dari tiga indikator dapat diketahui indikator tertinggi berada pada melaksanakan pengabdian dan terendah adalah adalah pada kualitas penunjang. Dosen perempuan masih kurang aktif dalam kegiatan-kegiatan sekstra seperti seminar, menjadi pejabat dalam sebuah organisasi. Hal ini lebih karena dosen perempuan memiliki pekerjaan utama yakni mengurus keluarga.

2. Kepuasan kerja dosen perempuan dengan skor 2.6 masuk dalam kategori kurang baik. Ini menunjukkan bahwa dosen perempuan dalam bekerja sebagai dosen merasa kurang puas. Dari tiga indikator yang digunakan untuk mengukur kepuasan kerja dapat dilihat indikator tertinggi pada puas dengan rekan sejawat dan paling rendah adalah pada kurang puas dalam menerima perlakuan dari lembaga kepadanya.

3. Sistem imbalan yang diterapkan di kampus menurut dosen perempuan, yakni dengan skor 2,23 masuk dalam kategori kurang baik. Ini menunjukkan bahwa dosen perempuan menganggap bahwa imbalan yang dibayarkan kepada dosen perempuan tidak sesuai dengan aturan pemerintah. Walaupun mereka menyatakan sudah sesuai dengan apa yang diberikan dengan apa yang diterimanya.

4. Sistem presensi menurut dosen perempuan kurang diterapkan dengan baik, hal ini dapat dilihat dari skor yang dihasilkan menunjukkan bahwa 2.53 masuk dalam kategori kurang baik. Hal ini disebabkan adanya anggapan dari dosen perempuan bahwa bekerja sebagai dosen bukan seperti bekerja sebagai karyawan pada sebuah perusahaan. Karena dosen merupakan jabatan professional jadi kehadiran bukan hal yang perlu di lakukan.

5. Sistem penghargaan yang diberikan sudah cukup baik. Dimana dari tiga indikator yang digunakan diketahui indikator yang paling rendah adalah pada sistem penghargaan hibah. Hal ini adanya anggapan bahwa melalui program hibah dikti, hal ini menjadi sebuah prestasi bagi dosen dengan diberikan penghargaan dalama bentuk ucapan selamat dari pimpinan akan menjadi sebuah bentuk apresiasi dari lembaga atas prestasi yang diraih dosen.

6. Pengaruh sistem imbahan signifikan dengan nilai signifikansi sebesar 0.01 lebih kecil dari 0.05 dan beta sebesar 0.79 yang berpengaruh positif. Kemudian pegaruh sistem presensi tidak signifikan dengan nilai signifikansi sebesar 0.45 lebih besar dari 0,05 dan nilain beta 0.01 . Juga pengaruh faktor sistem penghargaan dengan nilai signifikansi sebesar 0.29 juga lebih besar dari 0.05 dengan beta sebesar 0.05 . ini juga menunjukkan tidak signifikan terhadap kepuasan kerja.

7. Pengaruh kepuasan terhadap kinerja pegawai sebesar 0.01 lebih kecil dibandingkan dengan 0.05 menunjukkan pengaruh yang signifikan terhadap kinerja dosen perempuan.

Berdasarkan kesimpulan tersebut, maka dapat diberikan beberapa saran antara lain:

1. Tingkat kegiatan pengembangan wawasan dalam pelatihan dan seminar baik nasional maupun internasional, sehingga wawasan yang diperoleh dapat memberikan tambahan pengetahuan bagi dosen perempuan dan berguna dalam pengajarannya di kampus

2. Lembaga Kampus hendaknya 
memberikan perlakuan yang adil kepada dosen perempuan, walaupun dosen perempuan tidak senantiasa ada di kampus, namun mereka adalah bagian daripada dosen yang ada di kampus, berikan peran yang adil kepada mereka.

3. Berikan imbahan yang sesuai dengan aturan pemerintah, hal ini juga merupakan amanah pemerintah dalam memperlakukan tenaga kerjanya dalam bekerja. Minimal UMR.

4. Tidak perlu menerapkan presensi atau absensi kehadiran karena dosen bukan karyawan tetapi mereka adalah tenaga kerja professional dan mereka mampu mengatur pekerjaannya masing-masing.

5. Berikan penghargaan kepada dosen yang berprestasi, karena ini merupakan salah satu motivasi dari dosen dalam berkontribusi pada lembaga.

6. Untuk meningkatkan kepuasan kerja dosen diharapkan lembaga dapat menerapkan sistem imbalan yang adil kepada dosen dan minimal setara dengan UMR.

7. Diharapkan kepada lembaga untuk dapat meningkatkan kinerja dosen melalui usaha meningkatkan kepuasan dosen dalam bekerja.

\section{DAFTAR RUJUKAN}

Andiyanto, W., \& Darmastuti, I. (2011). Pengaruh Motivasi Kerja Dan Kepemimpinan Terhadap Kinerja Pegawai Pada Badan Keluarga Berencana Dan Pemberdayaan Perempuan Kabupaten Manggarai-Flores Nusa Tenggara Timur (Doctoral dissertation, Universitas Diponegoro)

Garniwa, I. (2007). Pengaruh stress kerja terhadap motivasi serta dampaknya terhadap prestasi kerja dosen tetap universitas widyatama.
Hakim, L. (2011). Pengaruh Motivasi Kerja Terhadap Kinerja Dosen STIE Totalwin Semarang. Jurnal Ilmu Manajemen dan Akuntansi Terapan (JIMAT), 2(2).

Karniawati, N. (2013). Kinerja Dosen Perempuan: Studi Relasi Gender di Unikom. J. Ilmiah Ilmu Politik dan Komunikasi, 1(1), 11-12.

Mulyandini, A. D. (2015). Self efficacy sebagai mediasi pengaruh work family conflict dan iklim kerja terhadap kinerja karyawati perbankan (studi pada dual career couple di bank bri dan bank btn cabang jember).

Rosita, S. (2014). Pengaruh Konflik Peran Ganda dan Stress Kerja terhadap Kinerja Dosen Wanita di Fakultas Ekonomi Universitas Jambi. Jurnal Manajemen Bisnis, 2(2).

Rusinta, A., Harsono, H., \& Maryati, T. (2013). Pengaruh Konflik Peran Ganda Terhadap Kinerja Pegawai Wanita dengan Stres Kerja Sebagai Variabel Pemediasi di Dinas Pendapatan Pengelolaan Keuangan dan Aset Kabupaten Kulon Progo. Jurnal Bisnis Teori \& Implementasi, 4(1), 1-30.

Tewal, B., \& Tewal, F. B. (2014). Pengaruh Konflik Peran Terhadap Kinerja Wanita Karir Pada Universitas Sam Ratulangi Manado. Jurnal Riset Ekonomi, Manajemen, Bisnis Dan Akuntansi, 2(1).

Engko, C. (2008). Pengaruh kepuasan kerja terhadap kinerja individual dengan self esteem dan self efficacy sebagai variabel intervening. Jurnal bisnis dan akuntansi, 10(1), 1-12. 
Sudiro, A. (2009). Pengaruh komitmen keorganisasian dan kepuasan kerja terhadap kinerja tenaga edukatif/dosen (studi di universitas brawijaya malang). Jurnal aplikasi manajemen, 7(1), 86-92.

Awaluddin, M. (2016, June). Pengaruh Budaya Organisasi, Kepuasan dan Lingkungan Kerja Terhadap Kinerja Dosen UIN Alauddin Makassar. In Assets (Vol. 6, No. 1, pp. 116125).

Hersusdadikawati, E. (2005). Pengaruh kepuasan atas gaji terhadap keinginan untuk berpindah kerja, dengan komitmen organisasional sebagai variabel intervening (Studi Empiris pada Dosen Akuntansi Perguruan Tinggi Swasta Jawa Tengah). Jurnal Studi Manajemen dan Organisasi (JSMO), 2(Nomor 1), 85-110.

Ariati, J. (2010). Subjective well-being (kesejahteraan subjektif) dan kepuasan kerja pada staf pengajar (dosen) di lingkungan fakultas psikologi universitas diponegoro. Jurnal Psikologi, 8(2), 117-123.

Ilmiana, Z. (2016). Analisis Perbandingan Penerapan Sistem Absensi Manual dan Finger Print Terhadap Disiplin Pegawai Negeri Sipil di Kantor Dinas Perindustrian Dan Perdagangan Kab. Gowa (Doctoral dissertation, Universitas Islam Negeri Alauddin Makassar).

Gandhi, M. A. (2017). Penerapan Absensi Finger Print Dalam Mendisiplinkan Kerja Pegawai Di Sekolah Menengah Kejurujan (Smk) Sekolah Menengah Tekhnik Industri (Smti) Bandar Lampung (Doctoral dissertation, UIN Raden Intan Lampung). 